\title{
Return migration and identity change: A Hungarian case study
}

\begin{abstract}
Gábor Lados This study analyses the identity changes expe(corresponding author) rienced by migrants returning to Hungary beDepartment of Economic and Social Geography University of Szeged, Hungary

E-mail: ladosg@geo.u-szeged.hu

Gábor Hegedüs

Department of Economic and Social Geography University of Szeged, Hungary E-mail: hegedusg@geo.u-szeged.hu fore, during, and after their stay abroad. Sussman's (2011) cultural identity change model is used as a theoretical framework to which two factors, 'skills' and 'family status' are added. Although identity change plays an important role in the success or failure of return, reintegration, and reemployment of returnees, to date this has not been studied in Hungary in detail. According to the research results, Hungarian returnees can be categorised into the same four groups as distinguished by Sussman (2011). Returnees in the affirmative identity group are found to be mostly low skilled migrants unable to integrate into the host society; as such, reintegration after their return is relatively easy. The members of the subtractive and additive identity groups can better integrate into the host country as they feel less attached to their native country than the affirmative group, but this causes various reintegration issues. The group

Keywords: of global identity shifters has the most natural emigration, reintegration process. Based on the research return migration, identity change, remigration initiatives,

Hungary results, it is recommended that Hungarian return migration policies and initiatives should give greater consideration to these reintegration differences.
\end{abstract}

\section{Introduction}

The emigration of manpower from both East-Central Europe and Hungary has exacerbated what is commonly known as the brain drain problem (Glaser-Habers 1974, Nadler et al. 2016, Siska-Szilasi et al. 2016). Return migration is not unprecedented in Europe; there have been many waves of migration and remigration throughout history, but this process reached significant numbers after the EUaccession of East-Central European states and after the more developed member states of the EU opened labour markets (Fassmann et al. 2014). Since the enlarge-

Regional Statistics, Vol. 9. No. 1. 2019: 150-167; DOI: 10.15196/RS090109 
ment of the EU in 2004, the free movement of workers has caused a significant number of emigrants (in millions) to leave East-Central Europe, creating complex problems related to the emigration of highly skilled workers such as physicians (Lados-Hegedûs 2016, Boros-Pál 2016, Glorius 2018). Evidence of re-emigration consists of different emigration or immigration flows, interpreted as circular migration (Illés 2018). The mobility of the various actors taking part in voluntary migration flows is increasing because of international socioeconomic transformation, through the increasing embeddedness into transnational networks or the growing number of migrants with multiple citizenships. For example, professionals belonging to the management team of transnational companies, or various migrations for transnational family reunification, also contribute to the mobility of migrants (Conway-Potter 2009, Sussman 2011, Illés-Kincses 2012).

The main objective of this study is to explore the characteristics of identity change of Hungarian emigrants with different work experiences, skills and knowledge before emigration, during and after their return. The study not only touches upon changes in identity that can be observed among returnees as a result of the different migration phases but also how the identity change process and the return are influenced by marital status, the type of work abroad and level of education.

Available relevant international and Hungarian literature was duly taken into account in this study. We used data on the Hungarian migration in the statistical analysis. Emigrants' return and the related identity changes were explored through an interview survey. A total of 48 in-depth interviews were carried out with highly and partially lower skilled individuals who returned to Hungary between 2012 and 2015 after a 1-10 year-long stay abroad. The snowball sampling technique was used for the selection of interviewees. However, given the sample size of our qualitative research, only approximate conclusions can be drawn.

\section{The definition of return migration and its theoretical approaches}

Since the 1980s, the scientific research on return has become increasingly significant in migration studies (Glaser-Habers 1974, Gmelch 1980, Cassarino 2004, van Houte-Davids 2008, de Haas 2010, Nadler et al. 2016). To date, the primary concern of Hungarian social geography has mainly focused on emigration in terms of several different migration processes, such as migration of refugees to Europe (Kocsis et al. 2016, Farkas-Dövényi 2018). Studies on return migration, its individual and social aspects, and the practical, economic-development utilisation of this phenomenon (Kovács et al. 2013, Lados-Hegedűs 2016, Csányi 2018) are even rarer. However, similarly to emigration and remigration, labour mobility has also increased in Hungary since 1990, including inland or cross-border commuting on a daily basis or less often (Illés-Kincses 2012, Kovács et al. 2015).

Regional Statistics, Vol. 9. No. 1. 2019: 150-167; DOI: 10.15196/RS090109 
The phenomenon of remigration is diversely defined and interpreted in several different theoretical frameworks (Gmelch 1980, Cassarino 2004, OECD 2008, van Houte-Davids 2008, Sussman 2011, Lados-Hegedűs 2016). The concept of returnees can also be interpreted in many ways. In our research, re-migrants are members of the economically active population aged 15 years and older who voluntarily returned to their country of origin after spending a certain amount of time as migrants in another country. Some researchers highlight the inaccuracy of placing returnees in a homogenous social group (van Houte-Davids 2008), as in the case of emigrants and their diasporas (Sinatti-Horst 2014, Sik-Szeitl 2016).

The effects of the return migration, the relationship between returnees, and the development of the home country are judged differently in the literature. The related countries' policies are also assessed differently (Cassarino 2004, Rédei 2007, van Houte-Davids 2008, de Haas 2010). Return migration may cause multiple effects on different scales, such as a macro-level geographical scale (nation, region, urban or rural area) and a micro-level scale (individuals, family). We identified some positive effects such as the labour market use of material, intellectual, and relational capital obtained abroad; remittances; contribution to modernisation in the form of technological and other innovations; and confidence building between members of the society (Rédei 2007, OECD 2008, Klein-Hitpaß 2016). Our findings indicate that returnees may also face negative effects: for example, they may find it difficult to reintegrate into their homeland's economy and society, and their material prosperity and 'success stories' may give rise to envy. These factors can trigger circular migration and the emigration of newer groups (Gmelch 1980, OECD 2008, van Houte-Davids 2008).

The generally interdisciplinary theories related to remigration (Cassarino 2004, Smoliner et al. 2013, Kunuroglu et al. 2016) can be grouped in several ways. Most migration theories seek to answer questions such as the emigration decision, its motivations, the development of social networks, the existence or absence of links between the receiving and the home country, and the mobility of capital obtained abroad. In a foreign environment, many different influences affect individuals' decisions, habits, and identity. However, migratory theories focus less on the personality of migrants, their identity, and their identity change (Sinatti-Horst 2014). Nevertheless, identity and identity change can have a significant impact on one's future migration decisions (Berry 1997, van Houte-Davids 2008, Sussman 2011). Individual resource mobilisation and preparedness are inherent factors that influence the success of emigration and remigration (Cassarino 2004). In our empirical research, we found that most of the emigrants and returnees tried to prepare for and plan their migration decisions, albeit with differing levels of awareness.

Analysing the identity change of returnees is not a mainstream theory in return migration research, but there are several cases in the literature (GullahornGullahorn 1963, Berry 1997, Sussman 2011). Sussman's (2011) cultural identity

Regional Statistics, Vol. 9. No. 1. 2019: 150-167; DOI: 10.15196/RS090109 
model underlines the shifts in the personal attributes of migrating individuals from a socio-psychological approach. The model examines the strengths and changes of one's attachment to the home and host countries during the whole migration process (before and during emigration, after return), focusing on migrants' cultural adaptation in the host country while maintaining their home identity. This theoretical construct helps us understand the identity changes of returnees, categorise them, and hypothesise the future migration decisions of returnees, that is, the probability of their settlement in the home country or the possibility of re-emigration. Sussman created the model based on a group of Hong Kong returnees. However, groups of returnees from America and Europe were also evaluated. We note that the homeland's historical and social context plays an important role in returnees' experiences of cultural transition, which must be observed in the model's application. According to our research, there is generally no significant negative prejudice against returnees in Hungary.

According to Sussman (2011), the adaptation to the host cultural values takes place in different ways while abroad. The Cultural Identity Model defines four different returnee identity group types (and shifts), which express a relationship to the identity of the country the returnees were originally from. It is difficult to distinguish between these group types, and the spatial comparisons based on the model are difficult to achieve with only a few identity change studies performed globally to date. Both macro- and micro-level factors determine each type: the characteristics of the sending and receiving countries, the extent to which emigrants should be attached to the home country's values, the generational differences among returnees, and the family roles. All these factors can have considerable influence on which group returnees from the same period and country may belong.

The affirmative identity shifters are firmly attached to their home culture identity while abroad, as they feel much better in their native country and are not so adaptive towards the host country's social values and culture. However, members of other two model groups may experience significant stress upon return. The return of the additive and subtractive groups occurs differently. Subtractive returnees are not intimately tied to the culture of either the home or the host country, and they try to learn as many new things as possible during their work abroad. However, due to stress after return, they often become alienated from their host and home countries. In several respects, the additive returnees resemble the subtractive group; the main difference between the two groups is the relationship to their home country cultures. The additive returnees retain and practice their own culture and traditions, but they are much more open to new influences experienced in the host country and usually adopt certain elements (e.g. attitude, work ethics, lifestyle). After returning, despite the stress involved, their connections with the host country will be retained. If changing their cultural identity after returning is difficult, then the re-emigration of the additive group is also possible (Sussman 2011).

Regional Statistics, Vol. 9. No. 1. 2019: 150-167; DOI: 10.15196/RS090109 
The author refers to the fourth, less common group as global identity returnees. Such individuals can carry multiple identities. They can follow and adapt individual cultural samples according to their current working and living conditions. However, this is neither facilitated by the mixing of cultural values from the home and the host country, nor by the development of a bicultural strategy. Members of this group consider themselves world citizens, so they can flexibly and quickly adapt to social requirements anywhere abroad. They are moderately positive about their return and ready to move abroad in the future for a shorter or longer period.

In our study, we held interviews with 48 returning Hungarian migrants. We also analysed the type of foreign employment held abroad, and the returning individuals were classified as lower and highly skilled. In our grouping, we assumed, partly because of their qualifications, migrants in lower-level jobs abroad are usually at a lower level of language skills than those working in higher positions.

\section{The European and Hungarian characteristics of return migration}

The following findings relate to the territorial characteristics of the migration. In Europe, the brain drain process is a migration from the East to the West. Unfortunately, there are no reliable statistical data on the level of emigration and return migration, as with other migration processes (Blaskó-Gödri 2016, Horváth 2016, Bálint et al. 2017), partly because those who actually reside abroad also include those who have left the country for less than a year and will therefore not appear in the statistical data. In many cases, the European Union Labour Force Survey data are used to interpret return migration. However, this survey examines the labour market situation of the population, and while it comprises data on previous employment abroad (more precisely a year ago), its applicability is very limited in the study of return migration. To date, the characteristics of returnees have not been studied in great detail. In the case of people returning to their post-socialist states, work experience in Western Europe, new skills acquired, and technical knowledge learnt abroad are appreciated in the homeland's labour market (Smoliner et al. 2013). Opinions differ regarding the financial profitability of returning migrants upon returning to their home country. Revenues of migrants returning to the homeland are usually higher compared to their revenues before emigration (Lang-Nadler 2014).

Following the enlargement of the European Union that began in 2004, millions of East-Central Europeans left their homeland given the possibility of the free movement of labour (see Table 1). In 2017, more than 8.5 million people from East-Central European region countries lived in other EU countries. Most of the EU regions affected by emigration are in the former socialist countries (Eurostat 2019). In absolute numbers, more people have migrated from Romania, Poland, and Bulgaria, and fewer people have migrated from relatively advanced countries such as the Czech Republic, Estonia, and Slovenia. In terms of the number of emigrants, 
Hungary ranks fifth among post-socialist countries. In addition, the proportion of emigrants in the entire home country's population is also an important indicator. The number of emigrants per ten thousand home country citizens is the highest in Romania, Lithuania, and Latvia, while it is the lowest in Hungary, Slovenia, and the Czech Republic. Irrespective of its extent, emigration can cause serious problems in many countries, such as shortage of skilled workers.

Table 1

\section{The number of East-Central European emigrants living in the European Union*}

\begin{tabular}{l|r|r|r|r}
\hline \multicolumn{1}{c|}{ Country/Region } & $2004-2007$ & $2008-2011$ & $2012-2015$ & 2016-2018 \\
& & & & \\
\hline Romania & 389.2 & 859.8 & $1,198.7$ & $1,622.9$ \\
Lithuania & 172.4 & 499.7 & 819.0 & $1,179.1$ \\
Croatia & 765.5 & 564.5 & 758.8 & $1,077.8$ \\
Bulgaria & 231.4 & 375.5 & 596.2 & $1,068.6$ \\
Latvia & 90.8 & 194.7 & 652.7 & 941.6 \\
Poland & 158.1 & 313.2 & 472.4 & 638.9 \\
Estonia & 189.5 & 280.9 & 436.9 & 628.3 \\
Slovakia & 180.3 & 251.7 & 407.2 & 621.5 \\
Hungary & 82.7 & 104.8 & 256.5 & 433.0 \\
Slovenia & 161.6 & 126.6 & 197.1 & 298.7 \\
Czech Republic & 55.2 & 60.6 & 81.0 & 149.5 \\
East-Central Europe & 218.1 & 385.3 & 576.5 & 817.0 \\
\hline
\end{tabular}

* The number of citizens living abroad per 10 thousand inhabitants.

Source: Own calculation based on the Eurostat (2019) database.

The proportion of people returning to East-Central Europe has increased significantly since 2004 (see Table 2). During the 2008 global economic crisis, especially in 2008-2009, a mass return migration occurred in most post-socialist countries, and since 2012, the number of returnees has begun to increase along with the increase in emigration. We found the highest rates are among Romanian and Lithuanian returnees.

Regional Statistics, Vol. 9. No. 1. 2019: 150-167; DOI: 10.15196/RS090109 
Table 2

The share and number of returnees to East-Central Europe

\begin{tabular}{l|r|r|r|r|r|r}
\hline \multirow{2}{*}{ Country/Region } & \multicolumn{3}{|c|}{ Proportion of returnees, \%a) } & \multicolumn{3}{|c}{$\begin{array}{r}\text { Number of returnees per 10 thousand } \\
\text { inhabitants }\end{array}$} \\
\cline { 2 - 7 } & $2004-2007$ & $2008-2011$ & $2012-2017$ & $2004-2007$ & $2008-2011$ & $2012-2017$ \\
\hline Romania & no data & 92.1 & 88.4 & no data & 64.6 & 67.0 \\
Lithuania & 68.8 & 79.9 & 76.6 & 14.9 & 23.3 & 56.1 \\
Estonia & 39.1 & 50.0 & 51.8 & 6.1 & 13.2 & 38.3 \\
Poland & 87.0 & 90.8 & 55.4 & 2.5 & 30.8 & 31.5 \\
Latvia & no data & 72.0 & 58.5 & no data & 34.5 & 29.2 \\
Hungary & 8.1 & 9.7 & 50.0 & 2.1 & 2.9 & 26.0 \\
Croatia & 92.8 & 60.7 & 50.9 & 34.4 & 16.7 & 14.3 \\
Slovenia & 9.1 & 12.8 & 17.6 & 8.5 & 14.2 & 13.3 \\
Bulgaria & 96.0 & no data & 39.7 & 2.0 & 0.0 & 12.0 \\
Slovakia & no data & 18.8 & 52.0 & no data & 2.2 & 6.0 \\
Czech Republic & 2.9 & 28.3 & 13.1 & 2.0 & 17.6 & 5.0 \\
East-Central Europe & 20.3 & 61.8 & 59.8 & 3.1 & 25.1 & 32.1 \\
\hline
\end{tabular}

a) In the given period, the proportion of citizens returning home compared to the average number of immigrants in a year.

Source: Own calculation based on the Eurostat (2019) database.

In 2016, more than $43 \%$ of Hungarians in EU countries lived in Germany, 21\% in the United Kingdom, and 16\% in Austria. The proportion of Hungarian citizens working abroad is not high compared to the other countries in East-Central Europe. Nevertheless, it is important to note that the rate of Hungarian emigration has increased three-and-a-half times since 2001 (Gödri 2015).

Greater human and relational capital provision will further increase the potential for emigration. Hungary is at the forefront of European countries with mediumlevel migratory tendencies. The three most significant potential destinations are Germany, Austria, and the United Kingdom (Sik-Szeitl 2016). The majority of emigrants are young males, generally aged 20-39 years. Furthermore, the proportion of people with higher education and the proportion of unmarried people is greater than that of the remaining population (Blaskó-Gödri 2016). Similar to emigrants, the aforementioned groups are in the majority among the returnees (Horváth 2016). Migration intention is the highest among young people, particularly the 21-30 age group (Siskáné Szilassi-Halász 2018).

Regional Statistics, Vol. 9. No. 1. 2019: 150-167; DOI: 10.15196/RS090109 
Returnees originally from Central and Eastern European countries are more likely to start their own business than those who remain, but unemployment rates may be higher in their group (Martin-Radu 2012, Horváth 2016). To date, only a few studies have been conducted to analyse the regional-local spatial characteristics of return within the home country (Kincses 2014, Apsite-Berina et al. 2018). According to the 2011 census (Kincses 2014) and the 2016 micro-census data (HCSO 2018), returning Hungarians adopt certain attitudes after their return when choosing their place of residence. They settle down mainly in the agglomeration of Budapest, in the vicinity of Lake Balaton and in more populous cities and towns outside Central Hungary. According to Kincses (2014), only 31\% of homebound migrants returned to their previous residences, which were presumably important to them. This phenomenon can be observed in other East-Central European states, including Poland, especially among highly qualified returnees (Klein-Hitpaß 2016).

In parallel with the migratory wave, the number of returning Hungarians has continuously increased. For instance, according to the Eurostat (2019) data, 32,557 people returned in 2015, which accounts for 56\% of all immigrants (excluding refugees) in Hungary. This rate has just been approaching the East-Central European average in the recent years. However, considering the statistical errors, we can conclude that the actual figures may be considerably higher.

Several programmes and initiatives tackling brain drain were implemented to minimise the negative effects of emigration and support return migration at various geographical scales (e.g. at the national, regional or local level) (Kovács et al. 2013, Lados-Hegedûs 2016). Currently no comprehensive migration policy dealing with out and return migration in the European Union exists (Kálmán 2016, Nadler et al. 2016). The majority of relevant short- and medium-term national policies and initiatives supporting return migration were developed and implemented in the 2000s. Evaluating the relatively new and delayed East-Central European initiatives is complicated (Kovács et al. 2013, Boros-Hegedűs 2016, Kálmán 2016).

A complex and comprehensive migration strategy has not yet been developed in Hungary; however, some initiatives focusing on specific target groups or areas of migration have been implemented. One of the most well-known and successful initiatives is the 'Lendület' ('Momentum') program founded by the Hungarian Academy of Sciences in 2009, which aims to re-attract young Hungarian researchers who have left the country. Another initiative is an NGO called 'Gyere Haza Alapítvány' ('Come Back Home Foundation'), which was founded in 2010. In 2013, it expanded its services to offer online and personal support to those out-migrants wishing to return. We can identify several retain-type programmes in the health care system or the Act CCIV of 2011 on National Higher Education. In 2015, the so-called 'Gyere Haza' ('Come Back Home') program was launched to re-attract young, higher educated Hungarians living in London and offered re-employment after return; the program ended in 2016 (Lados-Hegedús 2016).

Regional Statistics, Vol. 9. No. 1. 2019: 150-167; DOI: 10.15196/RS090109 


\section{Characteristics of Hungarian returnees and their identity change}

\section{Main characteristics of interviewees}

For the interview survey, returnees were divided into two groups according to their foreign work experience: lower and higher skilled returnees (see Table 3). The grouping was based on the hypothesis that emigrants working in jobs beneath their qualifications may return with less useful foreign work experience. Most of them, due to incomplete foreign language knowledge, were not or only partially integrated into the host society, and therefore their cultural identity and emotional attachment to their homeland remained relatively strong (Sussman 2011). Other influential factors included the length of stay abroad and marital status. The interview survey was based on Sussman's (2011) cultural identity change model, which compared foreign work experience and marital status. This method, along with a complex analysis of return migration, projects future migration strategies.

Similar patterns highlighted by international and national research were extracted from the interviews (Martin-Radu 2012, Horváth 2016). The majority of the sample comprised of men aged 20-34 years with a high level of education. The United Kingdom and the United States were overrepresented among the target countries, while Germany and Austria were underrepresented. Diverse migration paths illustrate the differences between returnees. Highly skilled returnees were more likely to have migrated greater geographical distances to achieve their goals and were likely to live in two or more countries. 
The personal data of highly skilled interviewees, 2012-2015

\begin{tabular}{l|l|l|l|l|l}
\hline $\begin{array}{c}\text { Inter- } \\
\text { view } \\
\text { num- } \\
\text { ber }\end{array}$ & Gender & Agea) & $\begin{array}{l}\text { Highest level } \\
\text { of education }\end{array}$ & $\begin{array}{l}\text { ISCO } \\
\text { category })\end{array}$ & \multicolumn{1}{|c}{ Target country/countries } \\
\hline I1 & male & $25-29$ & PhD & ISCO-21 & USA \\
I2 & female & $25-29$ & PhD & ISCO-21 & USA \\
I3 & male & $30-34$ & PhD & ISCO-21 & Germany \\
I4 & male & $30-34$ & PhD & ISCO-21 & USA \\
I5 & male & $30-34$ & PhD & ISCO-21 & USA, Netherlands \\
I6 & male & $25-29$ & university & ISCO-36 & United Kingdom \\
I7 & male & $30-34$ & PhD & ISCO-21 & Belgium, United Kingdom \\
I8 & male & $25-29$ & PhD & ISCO-21 & United Kingdom \\
I9 & male & $30-34$ & PhD & ISCO-21 & Australia \\
I10 & female & $20-24$ & college & ISCO-36 & United Kingdom \\
I11 & male & $25-29$ & PhD & ISCO-21 & United Kingdom, Italy \\
I12 & male & $25-29$ & PhD & ISCO-21 & United Kingdom, Switzerland, Germany \\
I13 & male & $30-34$ & university & ISCO-21 & Kazakhstan \\
I14 & male & $25-29$ & university & ISCO-21 & Ireland \\
I15 & female & $20-24$ & university & ISCO-24 & United Kingdom \\
I16 & male & $30-34$ & PhD & ISCO-21 & Denmark, Japan \\
I17 & female & $15-19$ & university & ISCO-25 & France \\
I18 & female & $30-34$ & PhD & ISCO-22 & USA \\
I19 & male & $25-29$ & PhD & ISCO-21 & United Kingdom \\
I20 & male & $25-29$ & PhD & ISCO-21 & Czech Republic \\
I21 & male & $40-44$ & PhD & ISCO-21 & USA \\
I22 & male & $20-24$ & PhD & ISCO-24 & USA \\
I23 & male & $25-29$ & university & ISCO-13 & Luxembourg \\
I24 & male & $25-29$ & PhD & ISCO-21 & USA \\
I25 & male & $25-29$ & university & ISCO-26 & Luxembourg \\
I26 & male & $25-29$ & high-school & ISCO-21 & Belgium, United Kingdom, Germany, \\
graduation & Spain \\
I27 & female & $25-29$ & university & ISCO-36 & Luxembourg \\
\hline male & $20-24$ & college & ISCO-24 & United Kingdom \\
\hline
\end{tabular}

(Continued on the next page.)

a) At the time of emigration.

b) Foreign work experience by International Standard Classification of Occupations' (ISCO) categories: ISCO1 = Legislators, senior officials, and managers; ISCO-2 = Professionals; ISCO-3 = Technicians and associate professionals; ISCO-4 = Clerks; ISCO-5 = Service workers and shop and market sales workers; ISCO-6 = Skilled agricultural and fishery workers; ISCO-7 = Craft and related trades workers; ISCO-8 = Plant and machine operators and assemblers; ISCO-9 = Elementary occupations. For the detailed classification structure, see https://www.ilo.org/public/english/bureau/stat/isco/

Regional Statistics, Vol. 9. No. 1. 2019: 150-167; DOI: 10.15196/RS090109 


\begin{tabular}{|c|c|c|c|c|c|}
\hline $\begin{array}{c}\text { Inter- } \\
\text { view } \\
\text { num- } \\
\text { ber }\end{array}$ & Gender & Age $^{a}$ & $\begin{array}{l}\text { Highest level } \\
\text { of education }\end{array}$ & $\begin{array}{c}\text { ISCO } \\
\text { categoryb) }\end{array}$ & Target country/countries \\
\hline I29 & male & $20-24$ & $\begin{array}{l}\text { professional } \\
\text { training }\end{array}$ & ISCO-51 & United Kingdom \\
\hline $\mathrm{I} 30$ & male & $25-29$ & $\begin{array}{l}\text { technical } \\
\text { school }\end{array}$ & ISCO-71 & Germany, Ireland \\
\hline $\mathrm{I} 31$ & male & $25-29$ & $\begin{array}{l}\text { technical } \\
\text { school }\end{array}$ & ISCO-71 & Kazakhstan \\
\hline $\mathrm{I} 32$ & female & $20-24$ & college & ISCO-41 & United Kingdom \\
\hline $\mathrm{I} 33$ & male & $40-44$ & university & ISCO-93 & Germany \\
\hline $\mathrm{I} 34$ & male & $50-54$ & college & ISCO-93 & Germany \\
\hline $\mathrm{I} 35$ & male & $20-24$ & college & ISCO-93 & Ireland \\
\hline I36 & male & $20-24$ & $\begin{array}{l}\text { technical } \\
\text { school }\end{array}$ & ISCO-93 & USA, United Kingdom, Sweden \\
\hline $\mathrm{I} 37$ & female & $25-29$ & college & ISCO-42 & United Kingdom, Ireland \\
\hline $\mathrm{I} 38$ & male & $30-34$ & $\begin{array}{l}\text { technical } \\
\text { school }\end{array}$ & ISCO-93 & Netherlands, Germany \\
\hline I39 & female & $20-24$ & university & ISCO-51 & Spain, United Kingdom \\
\hline $\mathrm{I} 40$ & female & $25-29$ & $\begin{array}{l}\text { professional } \\
\text { training }\end{array}$ & ISCO-51 & United Kingdom \\
\hline I41 & female & $25-29$ & college & ISCO-51 & United Kingdom \\
\hline I42 & female & $45-49$ & $\begin{array}{l}\text { technical } \\
\text { school }\end{array}$ & ISCO-51 & USA \\
\hline I43 & male & $25-29$ & $\begin{array}{l}\text { technical } \\
\text { school }\end{array}$ & ISCO-51 & United Kingdom \\
\hline $\mathrm{I} 44$ & male & $30-34$ & university & ISCO-51 & Estonia \\
\hline $\mathrm{I} 45$ & male & $40-44$ & $\begin{array}{l}\text { technical } \\
\text { school }\end{array}$ & ISCO-75 & Germany \\
\hline $\mathrm{I} 46$ & male & $25-29$ & university & ISCO-51 & United Kingdom \\
\hline $\mathrm{I} 47$ & male & $25-29$ & university & ISCO-51 & United Kingdom \\
\hline I48 & male & $30-34$ & $\begin{array}{l}\text { technical } \\
\text { school }\end{array}$ & ISCO-93 & Austria \\
\hline
\end{tabular}

a) At the time of emigration.

b) Foreign work experience by International Standard Classification of Occupations' (ISCO) categories: ISCO1 = Legislators, senior officials, and managers; ISCO-2 = Professionals; ISCO-3 = Technicians and associate professionals; ISCO-4 = Clerks; ISCO-5 = Service workers and shop and market sales workers; ISCO-6 = Skilled agricultural and fishery workers; ISCO-7 = Craft and related trades workers; ISCO-8 = Plant and machine operators and assemblers; ISCO-9 = Elementary occupations. For the detailed classification structure, see https://www.ilo.org/public/english/bureau/stat/isco/

In our opinion, the possible benefits of foreign work experience, that is, whether returnees are able to profit from emigration after return, depend on the type of foreign work. On one hand, those who worked in hospitality, construction, and food industry or had other manual jobs abroad (ISCO 4-9) were lower skilled mi-

Regional Statistics, Vol. 9. No. 1. 2019: 150-167; DOI: 10.15196/RS090109 
grants. On the other hand, those who worked as researchers, IT professionals, engineers, or doctors (ISCO 1-3) were identified as highly skilled migrants.

The sample's gender distribution indicates that the majority are male, which correlates with the literature (Horváth 2016). Those who emigrated with their family or as singles had different migration paths.

Lower skilled migrants returned with less useful work experience. Foreign language knowledge was typically not a primary requirement for those who worked in trained jobs, which means they worked with other Hungarians or immigrants from other countries who did not speak a foreign language.

Lower skilled migrants had more problems integrating in the host country than their highly skilled counterparts due to lack of language skills and unfamiliar working conditions. Their social relationships were superficial and fragile, and they broke after return. The main motivation for their emigration was a higher salary and accumulation of financial reserves abroad, as shown in previous studies (Martin-Radu 2012, Lang-Nadler 2014). They mainly held trained jobs abroad and were overqualified for their foreign jobs: 'Together with my partner, we planned to earn enough money for a house during our time abroad. It seemed completely absurd that we could have achieved this if we had stayed home (in Hungary)' (Mária ${ }^{1}$, female, unskilled worker). Another interviewee said the emigration plan was 'very easy. I could barely afford to pay for my home. It was much easier and more convenient to support them from abroad (...) though, we had a hard time living apart. Fortunately, it only worked for a while, after a while, my family moved' (Zoltán, male, butcher).

Those who had a higher level of education were categorised as a special subgroup; they did not work in their profession abroad and were overqualified for their foreign jobs. This may be regarded as brain waste (Személyi-Csanádi 2011). They could not return with newly acquired professional skills, but improved their language skills, which seemed to be beneficial after return.

Preparing for return was more common for highly skilled returnees, but not typical for all of them. The majority regarded emigration as temporary. Their main motivation was to improve their standard of living, financially (Horváth 2016) or professionally (e.g. career development). According to a young researcher who worked abroad for five years: In my profession, especially in the institute where I worked before, it was an unspoken expectation that a young researcher would go abroad to learn new methods for some years. It is thought to be a good way to start your career, and after the return, it might be also beneficial for your institution' (Zsolt, male, researcher). Highly skilled returnees worked in multicultural environments where they had colleagues from all over the world. Job advancement in their foreign workplace was achievable, depending on their knowledge and previous work experience. However, despite prosperous career

${ }^{1}$ The names of interviewees have been changed.

Regional Statistics, Vol. 9. No. 1. 2019: 150-167; DOI: 10.15196/RS090109 
paths, several interviewees stated they could only reach a certain position as immigrants; the host country's citizens occupied senior positions.

On the other hand, lower skilled migrants did not prepare as intentionally for emigration as highly skilled migrants. They usually made a quick decision to move abroad, even though many of them did not speak the language of the host country.

Our study showed that family ties were one of the most important motivations for Hungarians to return, in the same way as in previous studies (Martin-Radu 2012, Lang-Nadler 2014). According to the interviewees, family could be regarded as positive not just as negative motivation (e.g. return because of the death of a close relative). The fear of their children's assimilation led some interviewees to return home: I loved my foreign, well-paid job, but I always planned that my cbildren would grow up in Hungary as Hungarians' (Gergö, male, translator). Another returnee had a similar response: 'We always spoke in Hungarian to each other when we were at home. But later, my cbildren started to answer in English and refused to switch to Hungarian. Then I realised we spent enough time abroad (...) The environment was very inspiring to my children, but I did not want to see them losing their Hungarian identity' (Péter, male, researcher). This statement was reflected in other cases of families moving abroad.

Family did not influence emigration or return for single people because they stayed in contact with their relatives: Interestingly, there were friends and other relatives whom I spoke with more frequently, via Skype, than before my emigration (...) Of course, after some time, it was not regular' (János, male, waiter).

\section{Identity change of returnees}

Among the four groups of Sussman's (2011) identity change model, affirmative identity shifters formed the smallest group, similar to other international results. Those who had the worst working conditions abroad, the so-called 3D jobs (dirty, dangerous, difficult) (Gregory et al. 2009), were lower skilled migrants who left their families at home: Hungarians did not have a good reputation at my foreign workplace. We received the hardest tasks. Our superiors treated us in this way' (Géza, male, construction worker). They experienced return as a real relief and did not mention significant obstacles during re-integration. Their return may be regarded as a permanent migration decision.

Subtractive identity shifters were migrants who had lower skilled jobs abroad and emigrated with their spouse, children, or other family members. The expectation of higher wages and potential savings motivated them to leave the country. Their limited language skills did not particularly improve during the emigration. In the sample, subtractive and additive migrants were one of the most common identity types, somewhat different from Sussman's (2011) results which stated that subtractive migrants are the most common.

The meagre language skills of subtractive migrants determined their foreign working conditions. On one hand, they worked with other immigrants with basic

Regional Statistics, Vol. 9. No. 1. 2019: 150-167; DOI: 10.15196/RS090109 
foreign language skills, so they could not properly learn the host country's language. On the other hand, there was a native Hungarian atmosphere (mainly in trained jobs). Their families were generally closer to each other, which hindered integration in the host country. There were several obstacles following their return, such as reemployment in the Hungarian labour market. They could not utilise their foreign work experience after their return. Major barriers were migration plans made before the return that subtractive migrants were unable to fulfil, such as starting a family and having a stress-free, calm life without financial problems.

For subtractive and additive migrants, family was the most important motivation for return. Hence, the decision to move back was against their intentions and caused negative feelings about returning. Some who returned for family reasons mentioned clear migration plans for the future: 'Our children wanted to come back. We did not want to be separated from each other, so we followed them. When they finish secondary school, we [the parents] are sure to go abroad again because I cannot find any suitable job here' (Zoltán, male butcher).

According to these negative factors, lower skilled returnees are more likely to leave the country again, except for affirmative identity shifters; this suggests that subtractive, and to some extent, additive interview partners have found their reintegration as difficult as other European and non-European returnees (Sussman 2011). Hence, they could be regarded as potential circular migrants (Illés-Kincses 2012, Martin-Radu 2012).

Additive identity shifters fell into two sub-groups: lower skilled single people and highly skilled married people. The former sub-group included those with university degree who worked in underqualified jobs abroad. They tried to acquire as many new skills as they could during emigration in order to be more successful in the labour market after return. They mentioned their improved language skills (usually English or German) and multinational work experience. The latter sub-group returned with more skills and knowledge that could be beneficial in the labour market, but like with the subtractive returnees, they returned for external reasons (e.g. family): 'I would have gladly stayed abroad, but my child did not feel comfortable there (...) I chose my family over career (...) But on my own, I would not have returned. Nevertheless, as for my current workplace, I do not have anything to complain about' (Tamás, male, researcher).

According to the Sussman's (2011) identity change model, the most successful returnees are the global identity shifters, who changed the most during the migration process. Similarly, our study found that returnees with a global identity were the minority. They are mainly highly skilled single migrants and could improve both their professional and personal life abroad. During their emigration, they were able to acquire a new identity. One of them commented, First, I would position myself as a European, second, a Budapestan, and third, a Hungarian' (Szabolcs, male, translator). Highly skilled returnees experienced smoother re-employment in the Hungarian labour market than their lower skilled counterparts did due to their newly acquired

Regional Statistics, Vol. 9. No. 1. 2019: 150-167; DOI: 10.15196/RS090109 
skills (e.g. management skills, technological know-how) and because they did not cut ties with former employers. Furthermore, as a result of emigration, almost all of the interviewees with global identity were able to achieve career development. Their decision to return was not affected by family reasons as in the case of the members of the subtractive or additive groups.

\section{Conclusion}

In this paper we analysed the identity change of Hungarian returnees based on Sussman's identity change model. Statistical data on emigration and return migration are very limited, but according to these databases, the importance of both processes in Hungary is increasing. Our interview survey showed that the identity change model and classification could be adapted to Hungarian returnees. The original model did not include family status and foreign work experience in the evaluation of return migration, but we added these factors to our model. According to the results, highly skilled returnees were able to utilise their foreign work experience, and their broadened social and professional networks may be beneficial in the labour market. They faced fewer obstacles during the return process and self-assessed a more successful return than lower skilled returnees, who returned with less useful work experience and who could not develop skills useful for the labour market. They face more difficulties during reintegration in the home country and regard their return as less successful. Family status could affect the return of both lower and highly skilled migrants. Having a child or the fear of children's assimilation may motivate people to return. We can conclude that identity change should be considered during decision making and implementation of return initiatives. Moreover, foreign work experience, newly acquired skills and knowledge, and various family-related aspects (e.g. adequate social services) should be considered and adopted in the context of initiatives supporting return migration. 


\section{REFERENCES}

AbBa Apsite-BerinA, E.-KrisjAnE, Z.-SECHI, G.-BERZINS, M. (2018): Regional patterns of belonging among young Latvian returnees Economic Science for Rural Development Conference Proceedings 48: 77-84. https://doi.org/10.22616/esrd.2018.071

BÁlint, L.-CSÁNYI, Z.-FARKAS, M.-HLuChÁNY, H.-KinCSES, Á. (2017): International migration and official migration statistics in Hungary Regional Statistics 7(2): 101-123. https://doi.org/10.15196/rs070203

BERRY, J. W. (1997): Immigration, acculturation, and adaptation Applied psychology 46(1): 5-34. https://doi.org/10.1080/026999497378467

BLASKÓ, Zs.-GÖDRI, I. (2016): The social and demographic composition of emigrants from Hungary. In: BLASKÓ, Zs.-FAZEKAS, K. 2016: The Hungarian Labour Market 2016 pp. 60-68., Institute of Economics, Centre for Economic and Regional Studies, Hungarian Academy of Sciences, Budapest.

Boros, L.-HEGEDÛS, G. (2016): European national policies aimed at stimulating return migration. In: NADLER, R.-KOVÁCS, Z.-GLORIUS, B.-LANG, T. (eds.): Return migration and regional development in Europe: mobility against the stream pp. 333-357., Palgrave Macmillan, Basingstoke.

Boros, L.-PÁL, V. (2016): A magyarországi orvosmigráció néhány jellemzője ÉszakMagyarországi Stratégiai Füretek 13(1): 64-72.

CASSARINO, J-P. (2004): Theorising return migration: The conceptual approach to return migrants revisited International Journal on Multicultural Societies 6(2): 253-279.

CsÁNYI, Z. (2018): Exploring the behavioural aspects of migration decisions in the biography of a returner Análise Europeia 3(5): 58-90.

CONWAY, D.-POTTER, R. B. (2009): Return of the 'Next Generations': Transnational mobilities, family demographics and experiences, multi-local spaces. In: CONWAY, D.-PotTeR, R. B. (eds.): Return Migration of the Next Generations: 21st Century Transnational Mobility pp. 236-237., Ashgate, Farnham.

DE HAAS, H. (2010): Migration and development: a theoretical perspective International migration review 44(1): 227-264. https://doi.org/10.1111/j.1747-7379.2009.00804.x

EUROSTAT (2019): http://appsso.eurostat.ec.europa.eu/nui/show.do?dataset= migr_imm2ctz\&lang=en (accessed 22.05.2019.)

FARKAS, M.-DÖVÉNYI, Z. (2018): Migration to Europe and its demographic background Regional Statistics 8(1): 29-48. https://doi.org/10.15196/RS080103

Fassmann, H.-Musil, E.-BAuer, R.-Melegh, A.-Gruber, K. (2014): Longer-term demographic dynamics in South-East Europe: Convergent, divergent and delayed development paths Central and Eastern European Migration Review 3(2): 150-172.

GLASER, W. A.-HABERS, G. C. (1974): The migration and return of professionals International Migration Review 8(2): 227-244. https://doi.org/10.2307/3002782

GloRIUS, B. (2018): Migration to Germany: Structures, processes, and discourses Regional Statistics 8(1): 3-28. https://doi.org/10.15196/RS080101

Gmelch, G. (1980): Return migration American Review of Anthropology 9(1): 135-159. https://doi.org/10.1146/annurev.an.09.100180.001031

Regional Statistics, Vol. 9. No. 1. 2019: 150-167; DOI: 10.15196/RS090109 
GÖDRI, I. (2015): Nemzetközi vándorlás. In: MONOSTORI, J.-ŐRI, P.-SpéDER, Zs.: Demográfiai portré 2015 pp. 187-211., KSH Népességtudományi Kutatóintézet, Budapest.

Gregory, D.-JOhnston, R.-Pratt, G.-WATts, M. J.-Whatmore, S. (eds.) (2009): The dictionary of human geography Wiley-Blackwell, Chichester, 462-464.

Gullahorn, J. T.-Gullahorn, J. E. (1963): An extension of the U-Curve hypothesis Journal of Social Issues, 19(3): 33-47. https://doi.org/10.1111/j.1540-4560.1963.tb00447.x

HCSO (2018): Mikrocenzus 2016. Nemzetközi vándorlás. Hungarian Central Statistical Office, Budapest.

HorvÁTH, Á. (2016): Returning migrants. In: BLASKÓ, ZS.-FAZEKAS, K. 2016: The Hungarian Labour Market 2016 pp. 110-116., Institute of Economics, Centre for Economic and Regional Studies, Hungarian Academy of Sciences, Budapest.

Illés, S. (2018): Gazdasági válság és cirkuláció Területi Statisztika 58(1): 103-122. https://doi.org/10.15196/TS580105

ILLÉS, S.-KINCSES, Á. (2012): Hungary as receiving country for circulars Hungarian Geographical Bulletin 61(3): 197-218.

KÁlmán, J. (2016): Public policies encouraging return migration in Europe. In: BLASKÓ, Zs.-FAZEKAS, K. 2016: The Hungarian Labour Market 2016 pp. 117-121., Institute of Economics, Centre for Economic and Regional Studies, Hungarian Academy of Sciences, Budapest.

KINCSES, Á. (2014): Nemzetközi migrációs körkép Magyarországról a 2011-es népszámlálási adatok alapján Területi Statisztika 54(6): 590-605.

KLEIN-HitPAß, K. (2016): Return migrants as knowledge brokers and institutional innovators: New theoretical conceptualisations and the example of Poland. In: NADler, R.-KovÁcs, Z.-Glorius, B.-LANG, T. (eds.) (2016): Return migration and regional development in Europe: mobility against the stream pp. 333-357., Palgrave Macmillan, Basingstoke.

Kocsis, K.-Molnár SAnsum, J.-Kreinin, L.-Michalkó, G.-BOtTlik, Zs.-SZabó, B.BALIZS, D.-VARGA, GY. (2016): Geographical characteristics of contemporary international migration in and into Europe Hungarian Geographical Bulletin 65(4): 369-390. https://doi.org/10.15201/hungeobull.65.4.6

KovÁcs, Z.-Boros, L.-Hegedüs, G.-LAdos, G. (2013): Returning people to the homeland: Tools and methods supporting remigrants in a European context In: LANG, T. (ed.): Return Migration in Central Europe: Current trends and an analysis of policies supporting returning migrants pp. 58-94., Forum ifl. 21. Leibniz-Institut für Länderkunde, Leipzig.

KovÁcs, Z.-EGEDY, T.-SZABÓ, B. (2015): Az ingázás területi jellemzőinek változása Magyarországon a rendszerváltozás után Területi Statisztika 55(3): 233-253.

Kunuroglu, F.-VAn DE Vijver, F.-Yagmur, K. (2016): Return migration Online Readings in Psychology and Culture 8(2): 1. https://doi.org/10.9707/2307-0919.1143

LADOS, G.-HEGEDÚs, G. (2016): An evaluation of Hungarian return migration Hungarian Geographical Bulletin 65(4): 321-330. https://doi.org/10.15201/hungeobull.65.4.2

Regional Statistics, Vol. 9. No. 1. 2019: 150-167; DOI: 10.15196/RS090109 
LAnG, T.-NADleR, R. (eds.) (2014): Return migration to Central and Eastern Europe transnational migrants' perspectives and local businesses' needs Forum ifl.23. LeibnizInstitut für Länderkunde, Leipzig.

MARTIN, R.-RADU, D. (2012): Return migration: The experience of Eastern Europe International Migration 50(6): 109-128. https://doi.org/10.1111/j.1468-2435.2012.00762.x

NADler, R.-KovÁcs, Z.-Glorius, B.-LANG, T. (eds.) (2016): Return migration and regional development in Europe: mobility against the stream Palgrave Macmillan, Basingstoke.

OECD (2008): International migration outlook 2008, OECD Publishing, Paris.

RÉDEI, M. (2007): Hazautalások Kelet- és Közép-Európába Statiştikai Szemle 85(7): $581-601$.

SIK, E.-SzEITL, B. (2016): Migráció a mai Magyarországról Educatio 25(4): 546-557.

SinATTI, G.-Horst, C. (2014): Migrants as agents of development Ethnicities 1-19. https://doi.org/10.1177\%2F1468796814530120

SISKA-SZILASI, B.-KÓRÓDI, T.-VADNAI, P. (2016): Measuring and interpreting emigration intentions of Hungarians Hungarian Hungarian Geographical Bulletin 65(4): 361-368. https://doi.org/10.15201/hungeobull.65.4.5

SISKÁNÉ SZILASI, B.-HALÁSZ, L. (2018): Reasons and characteristics of the dynamizing emigration intention of the Hungarian youth Eastern European Business and Economics Journal 4(1): 79-96.

SMOLINER, S.-FÖRSCHNER, M.-HOCHGERNER, J.-NOVÁ, J. (2013): Comparative report on re-migration trends in Central and Eastern Europe. In: LANG, T. (ed.): Return Migration in Central Europe: Current trends and an analysis of policies supporting returning migrants Forum ifl. 21. pp. 11-57., Leibniz-Institut für Länderkunde, Leipzig.

Sussman, N. M. (2011): Return migration and identity. A global phenomenon, a Hong Kong case Hong Kong University Press, Hong Kong.

SZEMÉLYI, L.-CSANÁDI, M. (2011): Some sociological aspects of skilled migration from Hungary Acta Universitatis Sapientiae, Social Analysis 1(1): 27-46.

VAN HOUTE, M.-DAVIDS, T. (2008): Development and return migration: from policy panacea to migrant perspective sustainability Third World Quarterly 29(7): 1411-1429. https://doi.org/10.1080/01436590802386658

Regional Statistics, Vol. 9. No. 1. 2019: 150-167; DOI: 10.15196/RS090109 